\title{
Puls method for events simulation in a lot scale bioretention device
}

\section{Método de Puls aplicado a um sistema de biorretenção em escala de lote para simulação de eventos}

\author{
Lucas Tardelly Lins Mariz Ferreira ${ }^{1}$ (D), Marllus Gustavo Ferreira Passos das Neves ${ }^{1}$ (D) and \\ Vladimir Caramori Borges de Souza ${ }^{1}$ (ic \\ ${ }^{1}$ Universidade Federal de Alagoas, Maceió, AL, Brasil \\ E-mails: lucastlmf@gmail.com (LTLMF), marllus.neves@ctec.ufal.br (MGFPN),vcaramori@yahoo.com (VCBS)
}

Received: September 13, 2018 - Revised: June 21, 2019 - Accepted: July 04, 2019

\begin{abstract}
Bioretention is a technique applied to treat and reduce runoff generated in urban areas. Although these facilities present complex processes, a simple model with few parameters can be useful for its project. This paper reports an application of Puls method as a bioretention simulation quantitative tool for events. A bioretention device in real scale was installed and monitored using four level sensors and a tipping-bucket rain gauge, both with data loggers. The method was applied in two ways: the facility as a single reservoir; and the facility as two serial reservoirs. Outflows depended on a single infiltration rate in the first case $(\mathrm{K})$ and two infiltration rates in the second case (K1 and K2). The study used 15 events. Results showed suitable values for Nash-Sutcliffe (NS) and determination coefficients ( ${ }^{2}$ ) in the calibration phase, especially for bioretention simulated as a single reservoir, with NS values ranging from 0.64 to 0.95 . NS ranged from 0.80 to 0.95 in the calibration phase for the device simulated as two serial reservoirs. The validation phase achieved lower NS and $\mathrm{R}^{2}$ than calibration phase. Despite this, the present study suggests the Puls model as a good option for research on bioretention devices modelling.
\end{abstract}

Keywords: Bioretention; Compensatory techniques; LID; Puls model.

\section{RESUMO}

Biorretenção é uma técnica aplicada para tratar e reduzir o escoamento superficial gerado em áreas urbanas. Embora essas instalações apresentem processos complexos, um modelo simples com poucos parâmetros pode ser útil para seu projeto. Este artigo relata uma aplicação do método Puls como uma ferramenta quantitativa de simulação de biorretenção para eventos. Um dispositivo de biorretenção em escala real foi instalado e monitorado usando quatro sensores de nível e um pluviômetro de báscula, ambos com registradores de dados. O método foi aplicado de duas maneiras: a instalação como um único reservatório; e a instalação como dois reservatórios em série. As vazões dependiam de uma única taxa de infiltração no primeiro caso (K) e duas taxas de infiltração no segundo caso (K1 e K2). Foram utilizados 15 eventos e os resultados mostraram coeficientes de Nash-Sutcliffe (NS) e de determinação $\left(\mathrm{R}^{2}\right)$ adequados na fase de calibração, especialmente quando a biorretenção foi simulada como um único reservatório, com valores NS variando de 0,64 a 0,95. Quando o dispositivo foi simulado como dois reservatórios em série, os valores de NS variaram de 0,80 a 0,95 na fase de calibração. A fase de validação resultou em NS e R² menores que a fase de calibração. Apesar disso, o estudo apresentou o modelo de Puls como uma boa opção para a pesquisa em modelagem de dispositivos de biorretenção.

Palavras-chave: Biorretenção; Técnicas compensatórias; LID; Modelo de Puls. 


\section{INTRODUCTION}

Bioretention is a stormwater management technique, part of Low Impact Development (LID) approach to dampen peak flow rates and decrease runoff volumes. It also aims to increase local infiltration rates allowing storage in inner layers pores of the soil (HUNT et al., 2008). Aesthetically, this device occurs as gardens allocated in parking places, roadsides and residences (HUNT et al., 2015). Despite all benefits, hydraulics complexities, types of sediments and complex biological reactions difficult detailed simulations of bioretention by computational models (BARKDOLL et al., 2016).

\section{Some used models}

Common models used to simulate bioretention systems are DRAINMOD, RECARGA and SWMM (LIU et al., 2014; WINSTON; DORSEY; HUNT, 2016), GIFMod (MASSOUDIEH; AFLAKI; PANGULURI, 2016) and MUSIC (IMTEAZ et al., 2013).

DRAINMOD is a continuous simulation model. Brown, Skaggs and Hunt III (2013) used it to simulate bioretention cells in Nashville and Rocky Mount, North Carolina. Seepage parameters were easier calibrated when an internal water storage zone was present. Water levels could be used solely to calibrate the seepage parameters instead of trying to calibrate simultaneous processes. Initially, DRAINMOD was not designed to model runoff of urban areas, but it has been restructured to allow high temporal resolution inputs and outputs in these areas (LISENBEE; HATHAWAY; WINSTON, 2018).

RECARGA model simulates water movement over the entire bioretention, receiving data of soil moisture and water volume at each step of the process at the hydrological cycle (ATCHISON; POTTER; SEVERSON, 2006). Boancă et al. (2018) used this model and concluded that the variable soil texture is the most important element of control in the design and performance of bioretention cell, and hydraulic conductivity has a large effect on the duration of flooding in bioretention cell.

GIFMod (Green Infrastructure Flexible Model) can be used to simulate several facilities in the LID approach (MASSOUDIEH et al., 2017). MUSIC (Model for Urban Stormwater Improvement Conceptualization) simulates bioretention and other facilities that evolve dimensions and local soil properties (IMTEAZ et al., 2013). Montaseri, Hesami Afshar and Bozorg-Haddad (2015) used a combination of MUSIC and genetic algorithms to optimize a treatment train setting for the post-development scenario near the district of Central Canberra, in Australia.

SWMM (Storm Water Management Model) models bioretention as an artificial depression that contains planted vegetation in prepared soil layer to remove sediments and pollutants at runoff (ROSSMAN, 2015). Wang et al. (2016) e Li, Li and Li (2016) used it to simulate a bioretention facility.

Although a great variety of computational models are available to represent and evaluate bioretention systems, a model including important processes involved in biomass change, plant uptake and defoliation is required. This type of model can provide the identification of elements transferred to the groundwater (LIU et al., 2014).

\section{Use of Puls model}

Simple models also must be able to represent water balances. In Puls model, output flow rates are functions of input flow rates and reservoir features (ZOPPOU, 1999). Puls model has been gaining adepts to simulate source control facilities. For example, Barbassa, Angelini Sobrinha and Moruzzi (2014) applied it to evaluate the performance and assist the design of an infiltration well, and Tecedor et al. (2015), to modelling an infiltration plane.

Rosa (2016) employed the Puls method as one of the phases of BIRENICE model, created by the author to dimension and simulate a bioretention on a size bigger than a lot scale. Main parameters used were: return time, soil properties, catchment area and voids percentage. Infiltration, drain pipe, and infiltration plus drain pipe are the three ways to release water from a bioretention. According to Sievers and Pinheiro (2013), it is also possible to insert a coefficient to represent clogging. This method neglect evapotranspiration effect, but this omission may represent less than $1 \%$ in the reduction of output (JENNINGS, 2016).

The present research proposed the use of Puls Model (also known as Level Pool Routing) to simulate a quantitative process in a bioretention system at small-scale working as a reservoir where water output happened only by means of infiltration.

Therefore, the objective was to evaluate the application of a model based on Puls method treating the output as an infiltration rate and using monitoring quantitative data from the bioretention device. The motivation was the need to develop user-friendly models with few parameters so that managers can assess the benefits of these practices on hydrology (LIU et al., 2014). In Brazil, Rosa (2016) applied the software BIRENICE to simulate a bioretention in an urban catchment area of 2.3 ha. This study used the Puls model to simulate quantitative aspects only at a small-scale control.

\section{MATERIAL AND METHODS}

\section{Studied area}

A bioretention was installed, in real scale, at the Centre of Technology (CTEC), Federal University of Alagoas (UFAL), to retain and treat the roof runoff of a building called CEENG (Knowing and Experiencing Engineering - Conhecer e Experimentar a Engenharia, in Portuguese) and the grass runoff from a nearby area. Geographic coordinates are 9 $33^{\prime} 06.8^{\prime \prime} \mathrm{S} 35^{\circ} 46{ }^{\prime} 31.7^{\prime \prime} \mathrm{W}$ (Figure 1).

The monitored bioretention has a surface area of $6.64 \mathrm{~m}^{2}$ (Figure 1) and three layers separated by a geotextile blanket, which allows the movement of water inside the device, without communication between the different materials. The first layer, at the bottom, is above local soil and filled with $10 \mathrm{~cm}$ of sand. $72 \mathrm{~cm}$ of gravel called brita 1 fills the second layer, with granulometry ranging from $9.5 \mathrm{~mm}$ to $19 \mathrm{~mm}$ (BRASIL, 2009) and the third layer with $19 \mathrm{~cm}$ of black soil. These thicknesses represent mean values because they changed slowly along the length. Rosendo (2013) and Menezes (2015) detailed the sizing.

The surface of the device is around $30 \mathrm{~cm}$ below ground level. 9 Philodendron plants (popularly known as Imbé) were placed on the surface. According to Guihong and Ruijun (2017), this is 


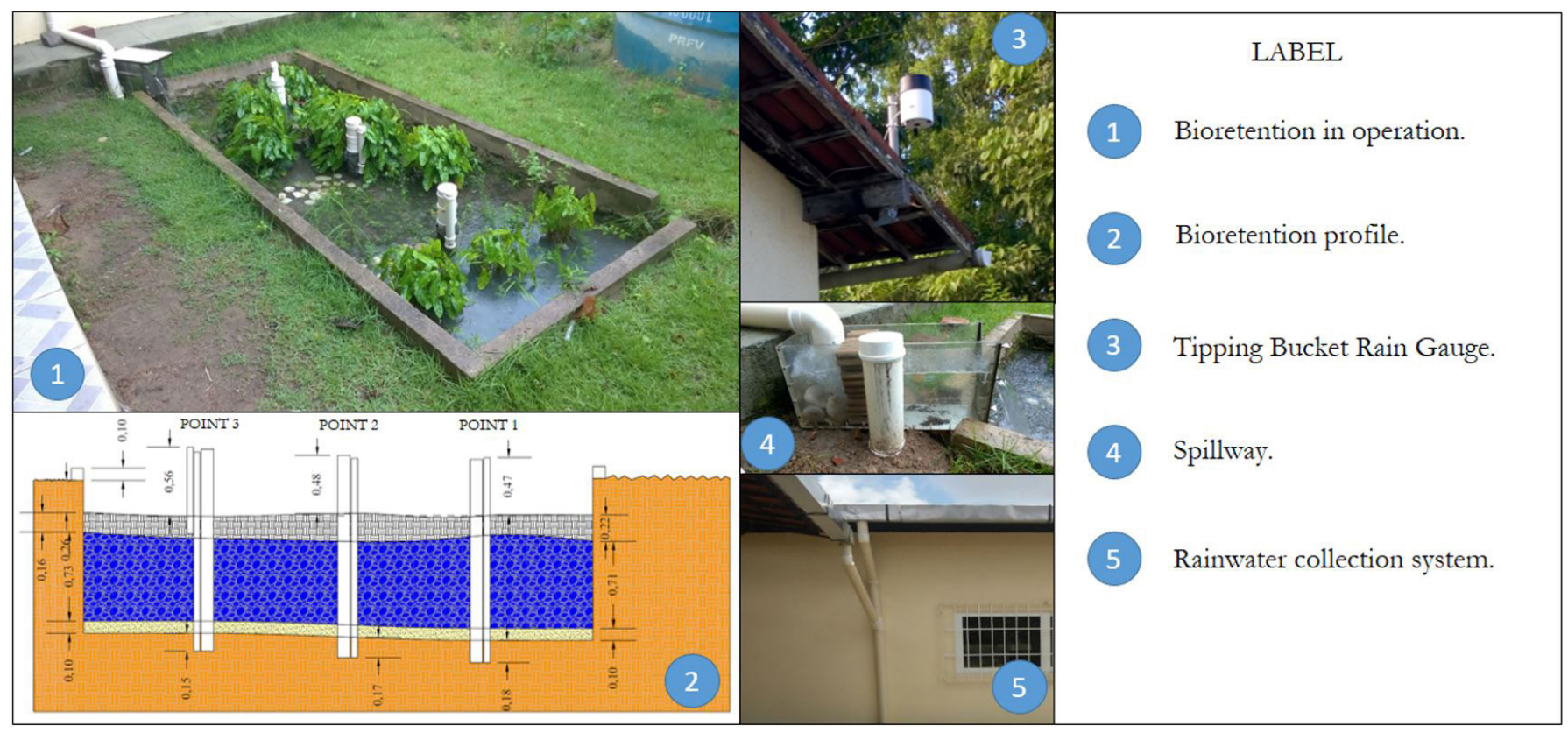

Figure 1. Components of bioretention.

one type of plant that can be applied in bioretention because its roots are great to improve layer structure and ornamentation, water retention and help to remove pollutants.

A tipping-bucket rain gauge was installed on a roof near the device $(15 \mathrm{~m})$ because is a safe place and far from trees. Three monitoring points were chosen for water balance and water quality (Figure 1). The levels were monitored using four level sensors. Three of them were at the bioretention and one was used at the spillway.

Figure 1 shows one level sensor at point 1 (far from spillway) used to verify the level inside the device, and two level sensors at point 3 (near the spillway) used to monitor the level inside the device (called S3) and above upper layer (called SS). Dynamics infiltration at the upper layer was observed, independently of the inner layer.

Collected data from sensors were formatted and separated into independent events. In this study, the word event means that precipitation raises water level inside the bioretention beyond sand layer, followed by a reduction to level zero recorded by sensors S1 and S3. No water elevation occurred during the next 12 hours, or during the 12 hours before events. Each event received a code following the Julian calendar with two units, according to the year, month and day that started the rain (YY/MM/ DD). For example, the event occurred on June 24, 2015, received code 150624.

\section{Puls model applied to bioretention}

Puls model used a discretized expression for lumped continuity equation (Equation 1) and a relationship between storage and output flow rate from a reservoir. Unknowns were flow rate $\mathrm{Q}$ and storage $\mathrm{S}$ at time $\mathrm{t}+1$. They were obtained using a level versus output flow rate curve (TUCCI, 2005). Discretized Equation 1 became Equation 2:

$\frac{\mathrm{S}_{\mathrm{t}+1}-\mathrm{S}_{\mathrm{t}}}{\Delta \mathrm{t}}=\frac{\mathrm{I}_{\mathrm{t}}+\mathrm{I}_{\mathrm{t}+1}}{2}-\frac{\mathrm{Q}_{\mathrm{t}}+\mathrm{Q}_{\mathrm{t}+1}}{2}$
$\mathrm{Q}_{\mathrm{t}+1}+\frac{2 \mathrm{~S}_{\mathrm{t}+1}}{\Delta \mathrm{t}}=\mathrm{I}_{\mathrm{t}}+\mathrm{I}_{\mathrm{t}+1}-\mathrm{Q}_{\mathrm{t}}+\frac{2 \mathrm{~S}_{\mathrm{t}}}{\Delta \mathrm{t}}$

where: $I_{t}$ and $I_{t+1}$ are input flow rate in the reservoir at time intervals $\mathrm{t}$ and $\mathrm{t}+1 ; \mathrm{Q}_{\mathrm{t}} \mathrm{e} \mathrm{Q}_{\mathrm{t}+1}$ are output discharge from the reservoir at time intervals $\mathrm{t}$ and $\mathrm{t}+1 ; \mathrm{S}_{\mathrm{t}} \mathrm{e} \mathrm{S}_{\mathrm{t}+1}$ are storages in the reservoir at time intervals $\mathrm{t}$ and $\mathrm{t}+1$; and $\Delta \mathrm{t}$ is the simulation time interval.

Output flow rate resulted from infiltration on the sides and bottom of the device. Angelini Sobrinha (2012) also considered this condition when modelled an infiltration well, and Lucas, Barbassa and Moruzzi (2013) when represented an infiltration trench. The discretized lumped continuity equation takes the form expressed in Equation 3.

$Q_{\text {inf } t+1}+\frac{2 S_{t+1}}{\Delta t}=I_{t}+I_{t+1}-Q_{\text {inf } t}+\frac{2 S_{t}}{\Delta t}$

The level versus flow rate curve was obtained using Equation 4, which presents a product of infiltration rate $(\mathrm{K})$ by the total infiltration area:

$\mathrm{Q}_{\mathrm{inf}}=\mathrm{K} \cdot[\mathrm{LC}+2 \mathrm{H}(\mathrm{L}+\mathrm{C})]$

where: $\mathrm{Q}_{\text {inf }}$ is the output flow rate by infiltration $\left(\mathrm{m}^{3} / \mathrm{s}\right) ; \mathrm{K}$ is the infiltration rate $(\mathrm{m} / \mathrm{s}) ; \mathrm{L}$ is the width of bioretention $(\mathrm{m}) ; \mathrm{C}$ is the length of bioretention (m); and $\mathrm{H}$ is the water level inside bioretention.

Traditional steps for simulation with Puls model are (LUCAS; BARBASSA; MORUZZI, 2013):

1. Plot $Q_{\text {inf }} \times H$ curve;

2. At the $t+1$ interval, the value of $\left[Q_{\text {inft }+1}+2 S_{t+1} / \Delta t\right]$ is determined because terms on the right of Equation 3 are known;

3. Output flow rate is obtained from $\left[\mathrm{Q}_{\text {inft }+1}+2 \mathrm{~S}_{\mathrm{t}+1} / \Delta \mathrm{t}\right]$ through Qinf x H curve;

4. The water level is calculated according to $\Delta \mathrm{t}$. 


\section{Simulating one and two reservoirs}

The method was applied in two pathways: the facility as a single reservoir, like an infiltration trench, in the first; and the facility as two serial reservoirs in the second. The output from the upper reservoir was the input to the lower reservoir. Therefore, in the first case, the parameter for calibration was a unique infiltration rate. In the second case, the parameters were the two infiltration rates.

A total of 37 rainfall events were recorded during the monitoring period between June 2015 and September 2016. This period was divided into two phases: in the first (23 events), water level monitoring performed from 2 level sensors and in the second phase (14 events), from 3 level sensors.

At the initial phase, selected events had maximum water levels greater than $20 \mathrm{~cm}$. This value was defined by a sand layer thickness of approximately $10 \mathrm{~cm}$. In the second phase, 3 events were selected because they have generated water level higher than surface level, above the upper layer of the bioretention (Table 1).

In the final phase of monitoring (May to September 2016), only $565 \mathrm{~mm}$ of precipitation were registered. This value is almost half of that value obtained in the same period of the previous year $(971.4 \mathrm{~mm})$. The second phase was much less rainy.

Table 1 presents the event code, total rainfall, rainfall duration and maximum water level inside bioretention. They were obtained at events monitoring from 150624 to 160529, collected from a tipping-bucket rain gauge, a calibrated spillway to provide input flow rates (hydrographs) and water level from level sensors inside bioretention at points S1 and S3.

Events 160602, 160619 and 160628 had the same information that previous events, and additional information from another level sensor used to measure water level in the upper layer. Thereby, it was possible to calibrate two infiltration rates, one at upper layer (level sensor SS) and other in the gravel layer (level sensors S1 and S2).

Data from events 150624 and 160529 were used to simulate bioretention like an infiltration trench, i.e., as a single water reservoir. In this case, it was necessary to determine fixed

Table 1. Events chosen to model the bioretention.

\begin{tabular}{ccccc}
\hline Quantity & Event & $\begin{array}{r}\text { Precipitation } \\
(\mathbf{m m})\end{array}$ & $\begin{array}{r}\text { Duration } \\
(\mathbf{h})\end{array}$ & $\begin{array}{c}\text { Maximum } \\
\text { level }(\mathbf{m})\end{array}$ \\
\hline 1 & 150624 & 63.2 & 18.2 & 1.06 \\
2 & 150722 & 42.4 & 36.8 & 1.09 \\
3 & 150815 & 8.8 & 7.3 & 0.25 \\
4 & 150818 & 10.6 & 10.0 & 0.27 \\
5 & 150820 & 63.6 & 28.8 & 0.93 \\
6 & 160121 & 15.4 & 2.7 & 0.74 \\
7 & 160129 & 28.2 & 5.2 & 0.44 \\
8 & 160413 & 45.4 & 31.8 & 1.05 \\
9 & 160424 & 16.6 & 6.8 & 0.27 \\
10 & 160522 & 37.8 & 9.2 & 0.70 \\
11 & 160524 & 14.6 & 7.3 & 0.38 \\
12 & 160529 & 146.8 & 33.1 & 1.19 \\
13 & 160602 & 22.4 & 13.4 & 0.34 \\
14 & 160619 & 29.6 & 24.2 & 0.47 \\
15 & 160628 & 16.0 & 9.3 & 0.28 \\
\hline
\end{tabular}

values for porosity and thickness for each layer, beyond calibrate infiltration rate per event.

Simulations of events 160602,160619 and 160628 were based on a structure with two serial reservoirs. The output hydrograph from the upper reservoir was the input hydrograph to the lower reservoir. Water level data from an area above the upper reservoir (level sensor SS) were used to calibrate the infiltration rate.

\section{Calibration and validation}

Infiltration rate was the only parameter calibrated. Calibration was performed by trial and error methods, and visualization of graphs. Nash-Sutcliffe (NS) and determination $\mathrm{R}^{2}$ coefficients were used in the evaluation of results. NS (Equation 5) ranges from 1 to $-\infty$, with 1 as ideal value (NASH; SUTCLIFFE, 1970) and $\mathrm{R}^{2}$ (Equation 6) ranges from 0 to 1 , with 1 as also ideal value (MONTGOMERY; RUNGER, 2010). Beyond them, relative error (E) was used to verify discrepancies between observed and simulated maximum water levels.

$$
\begin{aligned}
& \mathrm{NS}=1-\frac{\sum_{\mathrm{i}=1}^{\mathrm{n}}(\text { Xobs }-\mathrm{Xsim})^{2}}{\sum_{\mathrm{i}=1}^{\mathrm{n}}(\text { Xobs }-\overline{\text { Xsim }})^{2}} \\
& \mathrm{R}^{2}=\frac{\left[\sum_{\mathrm{i}=1}^{\mathrm{n}}(\text { Xobs }-\overline{\text { Xobs }}) \cdot(\text { Xsim }-\overline{\text { Xsim }})\right]^{2}}{\sum_{\mathrm{i}=1}^{\mathrm{n}}(\text { Xobs }-\overline{\text { Xobs }})^{2} \cdot \sum_{\mathrm{i}=1}^{\mathrm{n}}(\mathrm{X} \operatorname{Xim}-\overline{\mathrm{Xsim}})^{2}}
\end{aligned}
$$

where: $\mathrm{n}$ is the amount of data; Xobs is the observed data; $\overline{\mathrm{Xobs}}$ is the mean of observed data; Xsim is the simulated data; and $\overline{\mathrm{Xsim}}$ is the mean of observed data.

Roy-Poirier, Filion and Champagne (2015) used NS to compare simulated outflows. Figure 2 shows the outline used in the present study.

After inserting the Puls model in a worksheet, input flow rates $\left(\mathrm{m}^{3} / \mathrm{s}\right)$ and corresponding times were also inserted. A value
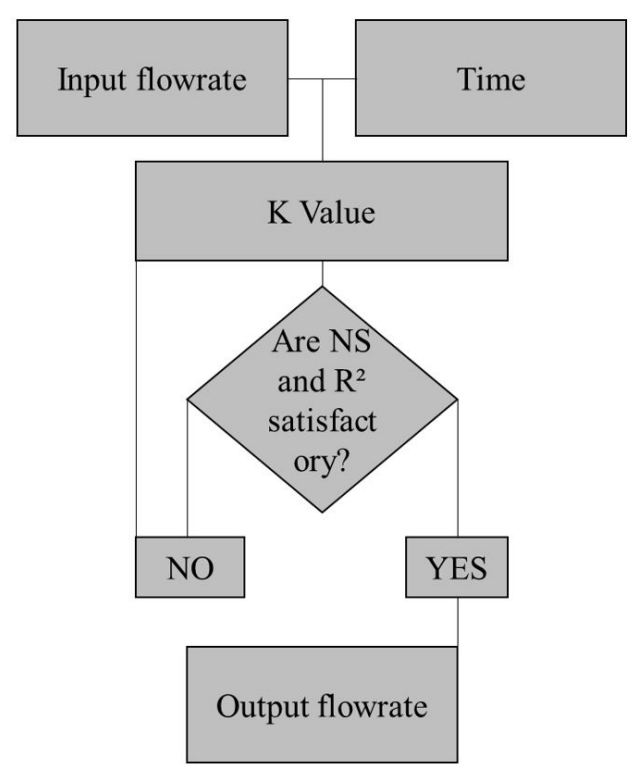

Figure 2. Flowchart of $\mathrm{K}$ calibration route (Bioretention as only one reservoir). 


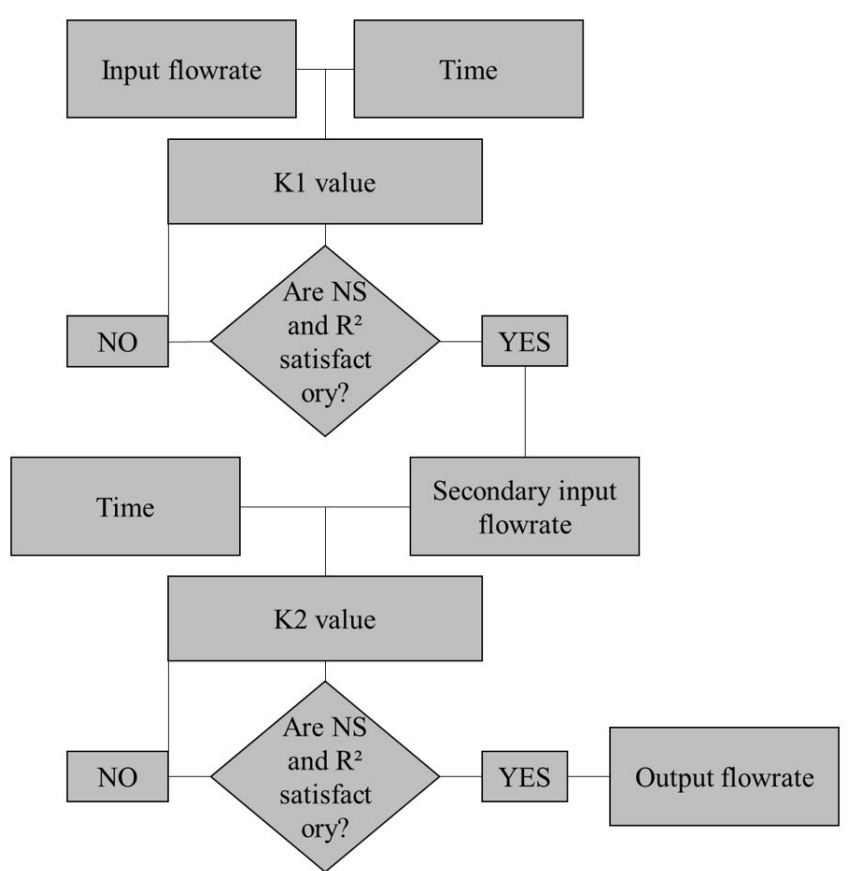

Figure 3. Flowchart of K calibration route (Bioretention as two serial reservoirs).

for $\mathrm{K}(\mathrm{mm} / \mathrm{h})$ was adopted and NS and $\mathrm{R}^{2}$ were calculated. In case of uncertainty, $K$ values were changed to approach 1 for NS and $R^{2}$. This procedure was performed for the first 9 events of Table 1 because 3 subsequent events were used at validation. Figure 3 shows the procedures to represent the bioretention with 2 reservoirs, similarly to Figure 2.

Validation was performed in two ways. The first used the infiltration rate mean value from events 160522,160524 e 160529. The second used the infiltration rate mean values from events where the bioretention was composed of two serial reservoirs, applying these values to simulate events without maximum levels above the upper layer.

Therefore, it was found $\mathrm{K} 1$ and $\mathrm{K} 2$ at the calibration process for events 160602, 160619 and 16062 . Then, these values were used to simulate events 240615, 220715, 150820 and 160529, chosen randomly to validate the values of parameters inside bioretention.

\section{RESULTS AND DISCUSSION}

\section{Simulating one reservoir}

Table 2 exhibits result from calibrations: events code, $\mathrm{K}$ values, maximum observed water levels, $\mathrm{N}^{\mathrm{S}}$ and $\mathrm{R}^{2}$ coefficients and relative error. NS varied from 0.64 to 0.95 . $\mathrm{R}^{2}$ varied from 0.80 to $0.95 . \mathrm{K}_{\text {med }}$ was $26 \mathrm{~mm} / \mathrm{h}$, different from the result achieved by Rosendo (2013) of $50 \mathrm{~mm} / \mathrm{h}$.

According to Ohnuma Júnior, Silva and Mendiondo (2015), the infiltration rate is influenced by rainfall duration and intensity. Sample linear correlation coefficient between $\mathrm{K}$ and mean rainfall intensity was 0.66 . Substituting rainfall intensity by rainfall duration, sample linear correlation coefficient decreased to -0.13 .

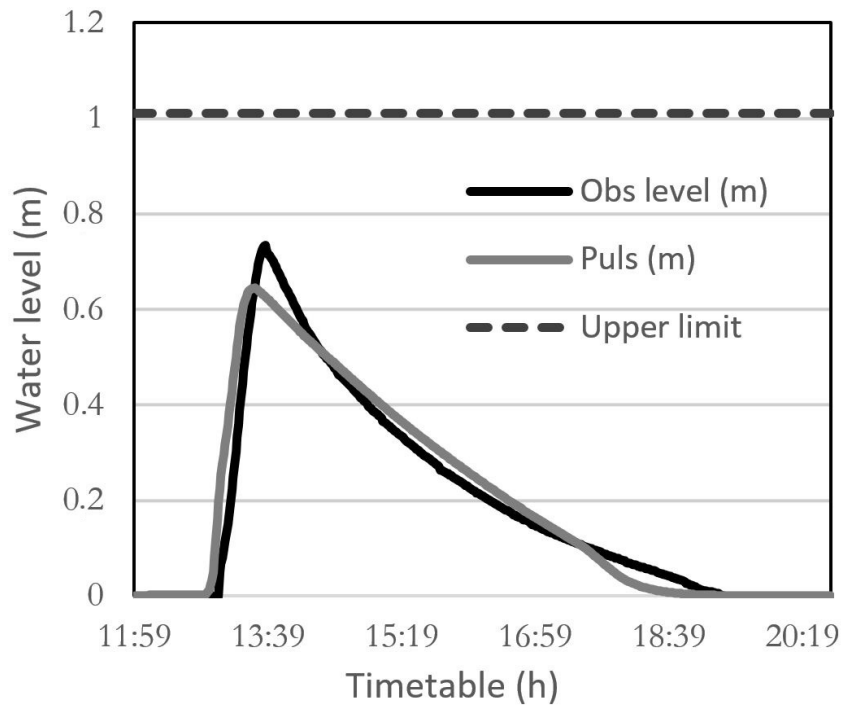

Figure 4. Event 160121.

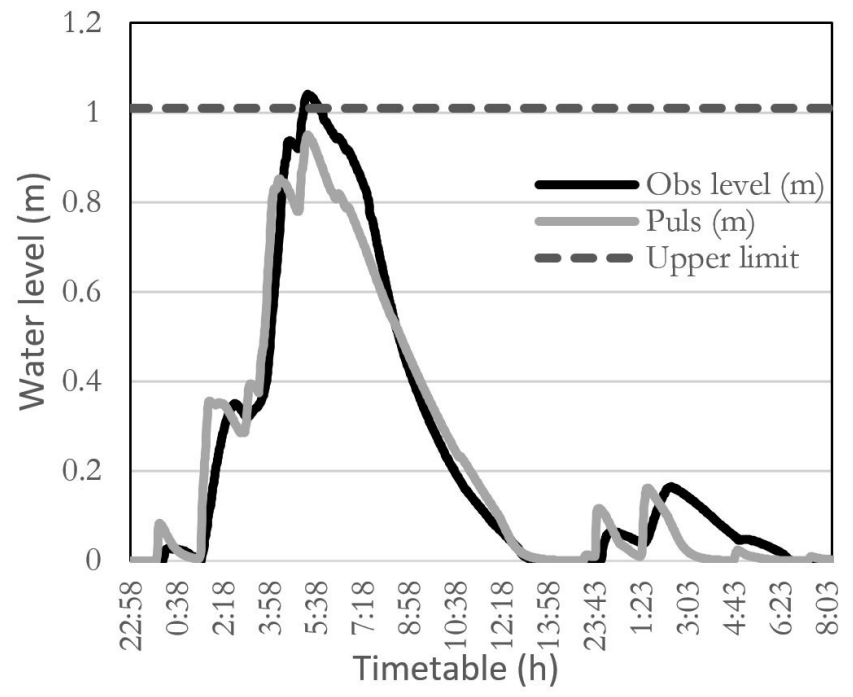

Figure 5. Event 160413.

Figures 4 and 5 show observed variations of water level (Obs. level), water level calculated (Puls) and upper limit of bioretention for the best coefficients in events 160121 and 160413.

While the maximum water level was inferior to the limit of the upper layer in Figure 4, the opposite happened in Figure 5. According to these figures, Puls model simulated the internal water level in a similar way to that observed with only one $\mathrm{K}$ calibrated as a parameter. Mean $\mathrm{R}^{2}$ was 0.88 and mean NS was 0.84 at the calibration.

Tecedor et al. (2015) used the Puls model to simulate an infiltration plane and found an average $\mathrm{R}^{2}$ of 0.72 . They used values for infiltration rates from a double ring infiltrometer test. Ferreira, Barbassa and Moruzzi (2018) modelled two infiltration wells and they found mean $\mathrm{R}^{2}$ of 0.92 and mean NS of 0.56 . They performed a calibration similar to this study. Both studies implemented experiments with total control of water input through precipitation event simulation. 
Table 2. Calibrated events for only $1 \mathrm{~K}$ value.

\begin{tabular}{|c|c|c|c|c|c|c|}
\hline Event & $\begin{array}{c}\mathrm{K} \\
(\mathrm{mm} / \mathrm{h})\end{array}$ & $\begin{array}{l}\text { Max. level } \\
(\mathrm{m})\end{array}$ & $\begin{array}{l}\text { Max. level. Puls } \\
\text { (m) }\end{array}$ & NS & $\mathbf{R}^{2}$ & $\begin{array}{c}\mathrm{E} \\
(\%)^{*} \\
\end{array}$ \\
\hline 150624 & 17 & 1.06 & 0.77 & 0.79 & 0.84 & 27 \\
\hline 150722 & 25 & 1.09 & 0.97 & 0.93 & 0.94 & 11 \\
\hline 150815 & 20 & 0.25 & 0.26 & 0.84 & 0.84 & 4 \\
\hline 150818 & 14 & 0.27 & 0.23 & 0.89 & 0.89 & 14 \\
\hline 150820 & 21 & 0.93 & 0.56 & 0.71 & 0.80 & 40 \\
\hline 160121 & 38 & 0.74 & 0.64 & 0.95 & 0.95 & 13 \\
\hline 160129 & 42 & 0.44 & 0.56 & 0.64 & 0.85 & 26 \\
\hline 160413 & 35 & 1.05 & 0.95 & 0.94 & 0.95 & 9 \\
\hline 160424 & 22 & 0.27 & 0.29 & 0.86 & 0.90 & 5 \\
\hline Mean & 26 & & & 0.84 & 0.88 & \\
\hline
\end{tabular}

Table 3. Calibrated events for two K values.

\begin{tabular}{|c|c|c|c|c|c|c|c|}
\hline Event & & $\mathrm{K}(\mathrm{mm} / \mathrm{h})$ & $\begin{array}{c}\text { Max. level } \\
(\mathrm{m})\end{array}$ & $\begin{array}{c}\text { Max. level. } \\
\text { Puls (m) }\end{array}$ & NS & $\mathbf{R}^{2}$ & $\mathrm{E}(\%)^{*}$ \\
\hline \multirow[t]{2}{*}{160602} & K1 & 87 & 0.21 & 0.14 & 0.88 & 0.93 & 30 \\
\hline & $\mathrm{K} 2$ & 31 & 0.34 & 0.29 & 0.91 & 0.91 & 14 \\
\hline \multirow[t]{2}{*}{160619} & K1 & 147 & 0.14 & 0.11 & 0.90 & 0.91 & 18 \\
\hline & $\mathrm{K} 2$ & 42 & 0.47 & 0.45 & 0.97 & 0.98 & 5 \\
\hline \multirow[t]{2}{*}{160628} & $\mathrm{~K} 1$ & 73 & 0.06 & 0.05 & 0.94 & 0.94 & 26 \\
\hline & $\mathrm{K} 2$ & 26 & 0.28 & 0.27 & 0.98 & 0.98 & 5 \\
\hline \multirow[t]{2}{*}{ Mean } & K1 & 102 & & & 0.90 & 0.93 & \\
\hline & $\mathrm{K} 2$ & 33 & & & 0.95 & 0.96 & \\
\hline
\end{tabular}

${ }^{*} \mathrm{E}(\%)=$ relative error.

\section{Simulating two reservoirs}

Table 3 presents the results of simulations considering the bioretention as two serial reservoirs. Results employed two values of $\mathrm{K}$ ( $\mathrm{K} 1$ and $\mathrm{K} 2$, for the first and the second reservoir, respectively). The first average $\mathrm{K}\left(\mathrm{K} 1_{\text {med }}=102 \mathrm{~mm} / \mathrm{h}\right)$ was the infiltration rate at the upper layer of bioretention. The second average $\mathrm{K}\left(\mathrm{K} 2_{\text {med }}=33 \mathrm{~mm} / \mathrm{h}\right)$ was the infiltration rate inside the device. $\mathrm{K} 1_{\text {med }}$ was between $70 \mathrm{~mm} / \mathrm{h}$ and $120 \mathrm{~mm} / \mathrm{h}$, found in the performed double ring infiltrometer test.

NS varied from 0.88 to 0.98 and $\mathrm{R}^{2}$ varied from 0.91 to 0.98 . The relative error between observed and simulated maximum levels was higher for the first reservoir, at event 160602. Calibration with two reservoirs was better than calibration with only one reservoir, evidencing the importance of monitoring two independent layers since they are able to store more water.

Figure 6 and Figure 7 display the performance of two bioretention reservoirs for the events 160619 and 160628 . Level zero refers to the bottom of bioretention and level 1 refers to the beginning of the upper reservoir. The rising water level inside bioretention begins at level zero, while water level reaches the surface of the device at level 1. Graphs show the variation of water level recorded in the upper layer level sensor (SS), water levels calculated in the upper layer (SS Puls), observed level variations (Obs level) and calculated level (Puls level) inside the device.

According to Figures 6 and 7, excellent agreement occurred between observed and simulated values for both first and second reservoirs. Table 3 discloses $\mathrm{K} 1$ and $\mathrm{K} 2$ had great variations. For events 160619 and 160628, K1 achieved $147 \mathrm{~mm} / \mathrm{h}$ and $73 \mathrm{~mm} / \mathrm{h}$, respectively. Probably, this happened because the Puls model was calibrated only using flow rate data provided by the spillway and by water level variation, ignoring other input volumes.

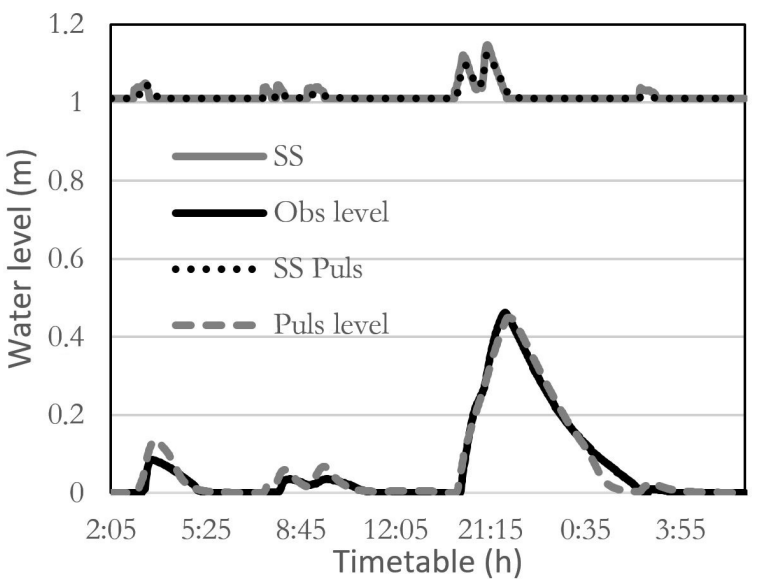

Figure 6. Event 160619.

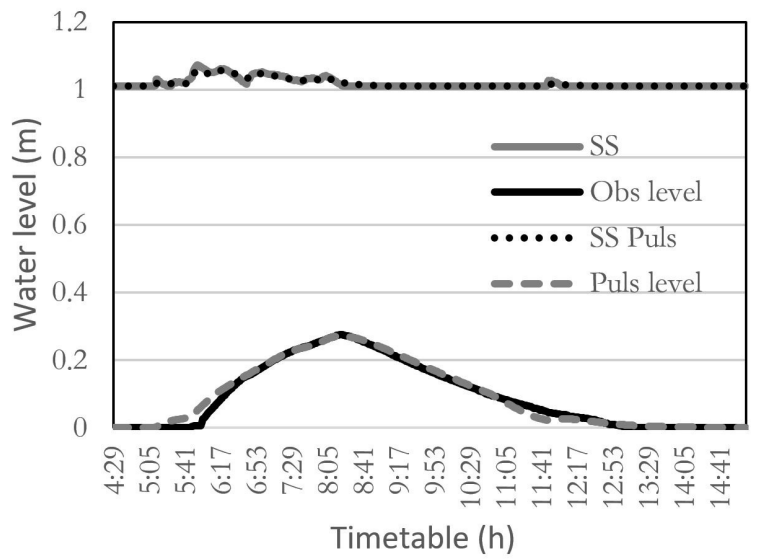

Figure 7. Event 160628. 
Table 4. Validation with one value for K.

\begin{tabular}{ccccccc}
\hline Event & K (mm/h) & Max. Level (m) & $\begin{array}{c}\text { Max. Level } \\
(\text { Puls) }(\mathbf{m})\end{array}$ & NS & $\mathbf{R}^{\mathbf{2}}$ & $\mathbf{E ~ ( \% )}^{*}$ \\
\hline 160522 & 26 & 0.70 & 0.74 & 0.76 & 0.93 & 6 \\
160524 & 26 & 0.38 & 0.39 & 0.85 & 0.90 & 3 \\
160529 & 26 & 1.19 & 1.77 & 0.48 & 0.27 & 49 \\
Mean & 26 & & & $\mathbf{0 . 7 0}$ & $\mathbf{0 . 7 0}$ & \\
\hline
\end{tabular}

$* \mathrm{E}(\%)=$ relative error.

Table 5. Validation with two values of $\mathrm{K}$.

\begin{tabular}{|c|c|c|c|c|c|c|}
\hline Event & $\mathrm{K}(\mathrm{mm} / \mathrm{h})$ & Max. Level (m) & $\begin{array}{c}\text { Max. Level } \\
\text { (Puls) (m) }\end{array}$ & NS & $\mathbf{R}^{2}$ & $\mathrm{E}(\%)^{*}$ \\
\hline \multirow[t]{2}{*}{150624} & 102 & - & 0.16 & - & - & - \\
\hline & 33 & 1.06 & 0.52 & 0.43 & 0.89 & 51 \\
\hline \multirow[t]{2}{*}{150722} & 102 & - & 0.17 & - & - & - \\
\hline & 33 & 1.09 & 0.62 & 0.89 & 0.88 & 43 \\
\hline \multirow[t]{2}{*}{150820} & 102 & - & 0.07 & - & - & - \\
\hline & 33 & 0.93 & 0.34 & 0.52 & 0.92 & 63 \\
\hline \multirow[t]{2}{*}{160529} & 102 & - & 0.33 & - & - & - \\
\hline & 33 & 1.19 & 1.05 & 0.60 & 0.67 & 11 \\
\hline \multirow[t]{2}{*}{ Mean } & 102 & & & - & - & \\
\hline & 33 & & & 0.61 & 0.84 & \\
\hline
\end{tabular}

$* \mathrm{E}(\%)=$ relative error.

Table 6. Mean coefficients values: calibration and validation.

\begin{tabular}{cccccc}
\hline \multirow{2}{*}{$\begin{array}{c}\text { Layers } \\
\text { quantity }\end{array}$} & \multicolumn{2}{c}{ Calibration } & & \multicolumn{2}{c}{ Validation } \\
\cline { 2 - 3 } \cline { 5 - 6 } & $\mathbf{N S}$ & $\mathbf{R}^{2}$ & & $\mathbf{N S}$ & $\mathbf{R}^{2}$ \\
\hline 1 & 0.84 & 0.88 & & 0.70 & 0.70 \\
& 0.90 & 0.93 & & - & - \\
& 0.95 & 0.96 & & 0.61 & 0.84 \\
\hline
\end{tabular}

\section{Validation}

Initially, the average parameter $\mathrm{K}$ was introduced in Puls model to simulate events 160522, 160524 and 160529 (Table 1). Table 4 summarizes the results of the validation, which provided suitable NS and $\mathrm{R}^{2}$ for events 220516 and 240516, while $\mathrm{K}$ of $26 \mathrm{~mm} / \mathrm{h}$ was not validated for event 290516.

Lucas, Barbassa and Moruzzi (2013) found a greater variation in NS coefficient and relative error (-0.98 to 0.98 and $3.1 \%$ to $68 \%$, respectively). They attributed this variation to simplifications in Puls model when considering constant infiltration and ignoring variation between initial and final infiltration capacity provided by the soil moistening. Tecedor et al. (2015) found mean $\mathrm{R}^{2}$ of 0.71 , similar to this study $(0.70)$ when considering the low value of the last event. Thus, in an attempt to calibrate a $\mathrm{K}$ to provide the best representation of event 160529, a value of $42 \mathrm{~mm} / \mathrm{h}$ was found.

Events 150624, 150722, 140820 and 160529 were used to validate $\mathrm{K}$ for two reservoirs. The lack of data recording by the level sensor at the SS point restricted the validation. Therefore, events from the first phase monitoring were used.

According to Table 5, NS and $\mathrm{R}^{2}$ varied from 0.43 to 0.89 and from 0.67 to 0.92 , respectively. In this case, NS were far from the unit, with the exception of event 150722. The relative error also showed high values. Adjustment of parameter $\mathrm{K}$ in the validation phase was insufficient in comparison with the calibration phase.
When comparing maximum levels calculated and observed, a high relative error was found in the first three simulations. This may have occurred because $\mathrm{K}$ calibration sample contained only 3 events, which may have been insufficient to perform calibration, also affecting validation. It would be more interesting to have a number of samples equivalent to that used in the calibration of bioretention as a single reservoir.

Another important point is that $\mathrm{K}$ is a constant value, which limits the representation of real infiltration process in the soil (ANGELINI SOBRINHA, 2012), although simulated 160619 and 160628 events were quite similar to the actual events. In addition, the quality of input data is important for better model calibration. Flow rate recorded at 1 -minute intervals may have been insufficient to represent the hydrographs. Shorter intervals may be better. Table 6 summarizes the average coefficients generated in both calibration and validation.

\section{CONCLUSION}

This study presented the Puls model as a good option for research on modelling the bioretention facility. 15 events were used, and results showed suitable Nash-Sutcliffe (NS) and determination coefficients $\left(\mathrm{R}^{2}\right)$ in calibration phase, especially for bioretention simulated as a single reservoir, with NS values ranging from 0.64 to 0.95 . When the device was simulated as two serial reservoirs, NS values ranged from 0.80 to 0.95 in the calibration phase. Despite acceptable NS and $\mathrm{R}^{2}$ in the calibration phase, determination of a single infiltration rate to represent bioretention was unfeasible.

The validation phase, using only three events, resulted in lower values of $\mathrm{NS}$ and $\mathrm{R}^{2}$ than in the calibration phase, especially for event 160529 . When bioretention was simulated as a single reservoir, values of NS ranged from 0.48 to 0.76 . When the 
device was simulated as two serial reservoirs, NS values ranged from 0.43 to 0.89 .

Further studies can be carried out to simulate groups of events with similar characteristics, such as total precipitation, climatic conditions and rainfall return time. It requires further steps, including soil moisture monitoring. It is also interesting to evaluate infiltration rates as a function of depth, a simple alternative that keeps the essence of Puls model. In this case, new calibration parameters can arise, making the model less sophisticated.

\section{ACKNOWLEDGEMENTS}

The authors acknowledge Finep (Redes Maplu-2 and Hidroeco), CNPq (Redes Maplu-2 and Hidroeco, Edital Universal), Capes and Fapeal (Edital Apoio a Pesquisas PPGs, and scolarship grant), and PPGRHS-Ctec-Ufal.

\section{REFERENCES}

ANGELINI SOBRINHA, L. Monitoramento e modelagem de um poço de infiltração de águas pluviais em escala real e com filtro na tampa. 2012. 147 f. Dissertação (Mestrado em Engenharia Urbana) Universidade Federal de São Carlos, São Carlos, 2012. Available from: <https://repositorio.ufscar.br/handle/ufscar/4324>. Access on: 10 july 2018.

ATCHISON, D.; POT'TER, K. W.; SEVERSON, L. Design guidelines for stormwater bioretention facilities. Wisconsin: Water Resources Institute, University of Wisconsin, 2006. 40 p. Publication $n^{\circ}$ WIS-WRI-06-01.

BARBASSA, A. P.; ANGELINI SOBRINHA, L.; MORUZZI, R. B. Poço de infiltração para controle de enchentes na fonte: avaliação das condições de operação e manutenção. Ambiente Construido, v. 14, n. 2, p. 91-107, 2014. http:/ /dx.doi.org/10.1590/ S1678-86212014000200007.

BARKDOLL, B. D.; KANTOR, C. M.; WESSELDYKE, E. S.; GHIMIRE, S. R. Stormwater low-impact development: a call to arms for hydraulic engineers. Journal of Hydraulic Engineering, v. 142, n. 8, p. 02516002, 2016. http://dx.doi.org/10.1061/(ASCE) HY.1943-7900.0001152.

BOANCĂ, P.; DUMITRAS, A.; LUCA, L.; BORS-OPRISA, S.; LACZI, E. Analysing bioretention hydraulics and runoff retention through numerical modelling using RECARGA: a case study in a Romanian urban area. Polish Journal of Environmental Studies, v. 27, n. 5, p. 1965-1973, 2018. http://dx.doi.org/10.15244/pjoes/79271.

BRASIL. Ministério das Minas e Energia. Contrato n 48000.003155/200717: desenvolvimento de estudos para elaboração do plano duodecenal (2010-2030) de geologia, mineração e transformação mineral. Produto 22: agregados para construção civil. Relatório técnico 30: perfil de brita para construção civil. Projeto Estal: projeto de assistência técnica ao setor de energia. Brasília, 2009.

BROWN, R. A.; SKAGGS, R. W.; HUNT III, W. F. Calibration and validation of DRAINMOD to model bioretention hydrology.
Journal of Hydrology, v. 486, p. 430-442, 2013. http://dx.doi. org/10.1016/j.jhydrol.2013.02.017.

FERREIRA, T. S.; BARBASSA, A. P.; MORUZZI, R. B. Controle de enchentes no lote por poço de infiltração de água pluvial sob nova concepção. Engenharia Sanitaria e Ambiental, v. 23, n. 3, p. $437-$ 446, 2018. http://dx.doi.org/10.1590/s1413-41522018161116.

GUIHONG, Z.; RUIJUN, X. Plant selection and application of rain garden in southern China. Journal of Landscape Research, v. 9, n. 3, p. 64, 2017.

HUNT, W. F.; LORD, B.; LOH, B.; SIA, A. Plant selection for bioretention systems and stormwater treatment practices. Singapore: Springer, 2015.

HUNT, W. F.; SMITH, J. T.; JADLOCKI, S. J.; HATHAWAY, J. M.; EUBANKS, P. R. Pollutant removal and peak flow mitigation by a bioretention cell in urban charlotte, N.C. Journal of Environmental Engineering, v. 134, n. 5, p. 403-408, 2008. http://dx.doi.org/10.1061/ (ASCE)0733-9372(2008)134:5(403).

IMTEAZ, M. A.; AHSAN, A.; RAHMAN, A.; MEKANIK, F. Modelling stormwater treatment systems using MUSIC: accuary. Resources, Conservation and Recycling, v. 71, p. 15-21, 2013. http:// dx.doi.org/10.1016/j.resconrec.2012.11.007.

JENNINGS, A. A. Residential rain garden performance in the climate zones of the contiguous United States. Journal of Environmental Engineering, v. 142, n. 12, p. 04016066, 2016. http:/ / dx.doi.org/10.1061/(ASCE)EE.1943-7870.0001143.

LI, J.; LI, Y.; LI, Y. SWMM-based evaluation of the effect of rain gardens on urbanized. Environmental Earth Sciences, v. 75, n. 1, p. 17, 2016. http:/ /dx.doi.org/10.1007/s12665-015-4807-7.

LISENBEE, W.; HATHAWAY, J.; WINSTON, R. Promoting successful urban watershed restoration through enhanced bioretention cell modelling. In: INTERNATIONAL CONFERENCE ON URBAN DRAINAGE MODELLING, 2018, Palermo, Italy. Proceedings... Cham: Springer, 2018. p. 280-284. https://doi. org/10.1007/978-3-319-99867-1_47.

LIU, J.; SAMPLE, D. J.; BELL, C.; GUAN, Y. Review and research needs of Bioretention used for the treatment of urban stormwater. Water, v. 6, n. 4, p. 1069-1099, 2014. http://dx.doi.org/10.3390/ w6041069.

LUCAS, A. H.; BARBASSA, A. P.; MORUZZI, E. B. Modelagem de um sistema filtro-vala-trincheira de infiltração pelo método de puls adaptado para calibração de parâmetros. Revista Brasileira de Recursos Hídricos, v. 18, n. 2, p. 225-236, 2013. http://dx.doi. org/10.21168/rbrh.v18n2.p225-236.

MASSOUDIEH, A.; AFLAKI, S.; PANGULURI, S. User's manual for green infrastructure flexible model (GIFMod). Washington: GIFMod, 2016. 
MASSOUDIEH, A.; MAGHREBI, M.; KAMRANI, B.; NIETCH, C.; TRYBY, M.; AFLAKI, S.; PANGULURI, S. A flexible modelling framework for hydraulic and water quality performance assessment of stormwater green infrastructure. Environmental Modelling \& Software, v. 92, p. 57-73, 2017. http://dx.doi.org/10.1016/j. envsoft.2017.02.013.

MENEZES, M. C. Construção de um dispositivo de biorretenção no Centro de Tecnologia da Universidade Federal de Alagoas. 2015. 72 f. Monografia (Graduação em Engenharia Civil) - Universidade Federal de Alagoas, Maceió, 2015.

MONTASERI, M.; HESAMI AFSHAR, M.; BOZORG-HADDAD, O. Development of simulation-optimization model (MUSIC-GA) for urban stormwater management. Water Resources Management, v. 29 , n. 13, p. 4649-4665, 2015. http://dx.doi.org/10.1007/ s11269-015-1082-z.

MONTGOMERY, D. C.; RUNGER, G. C. Applied statistic and probability for engineers. New Jersey: John Wiley \& Sons, 2010. 820 p.

NASH, J. E.; SUTCLIFFE, J. V. River flow forecasting through conceptual models part I: a discussion of principles. Journal of Hydrology, v. 10, n. 3, p. 282-290, 1970. http://dx.doi.org/10.1016/00221694(70)90255-6.

OHNUMA JÚNIOR, A. A.; SILVA, L. P.; MENDIONDO, E. M. Vazões afluentes em trincheira de infiltração domiciliar. Ciência \& Engenharia, v. 24, n. 1, p. 89-98, 2015. http://dx.doi.org/10.1 4393/19834071.2015.29927.

ROSA, A. Bioretention for diffuse pollution control in SUDS using experimentaladaptive approaches of ecobydrology. 2016. 123 f. Tese (Doutorado em Hidráulica e Engenharia Sanitária) - Universidade Federal de São Carlos, São Carlos, 2016. Available from: <http://www.teses.usp. br/teses/disponiveis/18/18138/tde-24032017 100208/publico/ OFFICIAL_THESIS_Final.pdf>. Access on: 10 july 2018.

ROSENDO, A. A. Avaliação de métodos e critérios para dimensionamento de dispositivos de bioretention. 2013. 63 f. Monografia (Graduação em Engenharia Civil) - Universidade Federal de Alagoas, Maceió, 2013.

ROSSMAN, L. EPA/600/R-14/413 (NTIS EPA/600/R-14/413b): storm water management model user's manual Version 5.1: manual. Washington: US EPA Office of Research and Development, 2015.
ROY-POIRIER, A.; FILION, Y.; CHAMPAGNE, P. An eventbased hydrologic simulation model for bioretention systems. Water Science and Technology, v. 72, n. 9, p. 1524-1533, 2015. http://dx.doi. org/10.2166/wst.2015.368. PMid:26524443.

SIEVERS, C. K.; PINHEIRO, A. Trincheira de infiltração em série com reservatório de água de chuva. Revista de Estudos Ambientais, v. 15 , n. 1 , p. 52-59, 2013.

TECEDOR, N.; BARBASSA, A. P.; MORUZZI, R.; GONÇALVES, M. L. Monitoramento e modelagem hidrológica de plano de infiltração construído em escala real. Revista Brasileira de Recursos Hídricos, v. 20, n. 3, p. 594-604, 2015. http://dx.doi.org/10.21168/ rbrh.v20n3.p594-604.

TUCCI, C. E. M. Modelos hidrológicos. 2. ed. Porto Alegre: Editora UFRGS, 2005. 678 p.

WANG, M.; ZHANG, D.; ADHITYAN, A.; NG, W. J.; DONG, J.; TAN, S. K. Assessing cost-effectiveness of bioretention on stormwater in response to climate change and urbanization for future scenarios. Journal of Hydrology, v. 543, p. 423-432, 2016. http://dx.doi.org/10.1016/j.jhydrol.2016.10.019.

WINSTON, R. J.; DORSEY, J. D.; HUNT, W. F. Quantifying volume reduction and peak flow mitigation for three bioretention cells in clay soils in northeast Ohio. The Science of the Total Environment, v. 553, p. 83-95, 2016. http://dx.doi.org/10.1016/j.scitotenv.2016.02.081. PMid:26906696.

ZOPPOU, C. Reverse routing of flood hydrographs using level pool routing. Journal of Hydrologic Engineering, v. 54, n. 2, p. 184-188, 1999. http://dx.doi.org/10.1061/(ASCE)10840699(1999)4:2(184).

\section{Authors contributions}

Lucas Tardelly Lins Mariz Ferreira: Execution, analysis, Portuguese writing.

Marllus Gustavo Ferreira Passos das Neves: Study design, manuscript review, analysis, English writing.

Vladimir Caramori Borges de Souza: Study design, manuscript review, analysis, English writing review. 